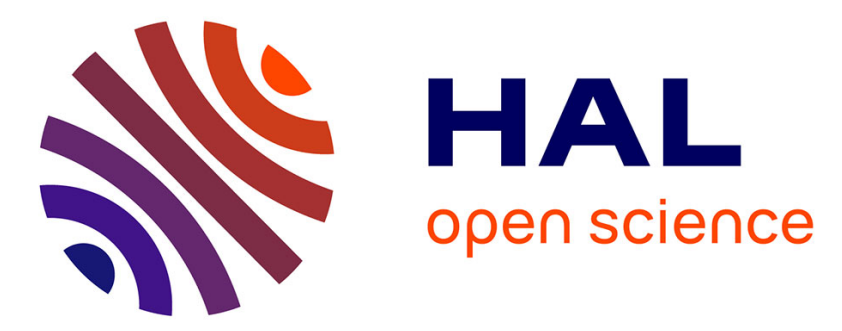

\title{
EELS ANALYSIS OF A PRECIPITATE IN V3Si BY STEM AND HVEM
}

A. Ben Lamine, F. Reynaud, C. Colliex, M. Acheche, Jean Sévely, Yolande

Kihn

\section{- To cite this version:}

A. Ben Lamine, F. Reynaud, C. Colliex, M. Acheche, Jean Sévely, et al.. EELS ANALYSIS OF A PRECIPITATE IN V3Si BY STEM AND HVEM. Journal de Physique Colloques, 1984, 45 (C2), pp.C2-709-C2-712. 10.1051/jphyscol:19842164 . jpa-00223837

\section{HAL Id: jpa-00223837 https://hal.science/jpa-00223837}

Submitted on 1 Jan 1984

HAL is a multi-disciplinary open access archive for the deposit and dissemination of scientific research documents, whether they are published or not. The documents may come from teaching and research institutions in France or abroad, or from public or private research centers.
L'archive ouverte pluridisciplinaire HAL, est destinée au dépôt et à la diffusion de documents scientifiques de niveau recherche, publiés ou non, émanant des établissements d'enseignement et de recherche français ou étrangers, des laboratoires publics ou privés. 


\section{EELS ANALYSIS OF A PRECIPITATE IN $V_{3} S i$ BY STEM AND HVEM}

A. Ben Lamine, F. Reynaud, C. Co11iex ${ }^{*}$, M. Acheche ${ }^{*}$, J. Sevely and Y. Kihn

Laboratoire d'optique EZectronique du CNRS, B.P. 4347, 31055 Toutouse Cedex, France

*aboratoire de Physique des Solides, Université Paris-Sud, Bât. 510, 91405 orsay Cedex, France

Résumé - Nous avons effectué l'analyse d'un précipité dans $V_{3} S i$ (structure A15) par spectroscopie de pertes d'énergie en microscopie électronique classique à haute tension $(1000 \mathrm{kV})$ et à balayage $(100 \mathrm{kV})$, par transmission. Compte tenu du diagramme de phases du système binaire V-Si, l'analyse a permis de penser qu'il s'agissait de $V_{5} \mathrm{Si}_{3}$. Ce résultat a été confirmé par microdiffraction électronique en faisceau convergent.

Abstract - The analysis of a precipitate in $\mathrm{V}_{3} \mathrm{Si}$ (A15 structure) has been performed by transmission EELS with a HVEM (1000 kV) and with a STEM (100 kV). Taking into account the phase diagram of the $V-S i$ system, the composition $V_{5} S_{3}$ is anticipated. This result has been confirmed by convergent beam electron microdiffraction.

A new lattice defect has been found /1/ by TEM in the $V_{5} \mathrm{Si}_{3}$ superconducting compound (A15 structure, Fig. 1). It looks like a couple of dislocation $1 \mathrm{i}$ nes parallel to the $\langle 100\rangle$ directions and it has been analyzed as a a/2 $\langle 100\rangle$ faulted dipole /2/ by matching conventional electron micrographs (Fig. 2) with computer simulations. However, residual contrast has been observed /3/ in the case of perfect theoretical extinction of the faulted dipole $(\vec{g} \cdot \vec{b}=0, \vec{g} \cdot \vec{b} \vec{u}=0$ and $A=0.97$ at room temperature). It has been first erroneously postulated /4/ that this defect could be a dispiration /5/ dipole. We have then been led to postulate the hypothesis that the faulted dipole accounted for the plastic deformation of the $\mathrm{V}_{3} \mathrm{Si}$ matrix caused by a needle-shaped precipitate. The purpose of this communication is to report the analysis of this precipitate by Electron Energy Loss Spectroscopy (EELS) and convergent beam electron microdiffraction.



Fig. 1 - Unit cell of $\mathrm{V}_{3} \mathrm{Si}$ (A15 structure).

\section{I - EXPERIMENTAL PROCEDURE}

The chemical analysis of the precipitate has been performed by EELS using both the 1.5 MV HVEM of the Laboratoire d! Optique Electronique (LOE) du C.N.R.S. de Toulouse operating at $1 \mathrm{MV} / 6,7 /$ and the $100 \mathrm{kV}$ VG-HB501 STEM of the Laboratoire de Physique des Solides d'Orsay /8/. The crystallographic study of the precipitate has been undertaken with the $120 \mathrm{kV}$ Philips EM400 of the L.0.E. equipped with a field emission gun.

The precipitate, which is elongated along the $<100>$ directions and the rectangular cross section of which is of the order of $40-80 \mathrm{~nm} \times 10-15 \mathrm{~nm}$ is set parallel to the incident electron beam in $a \simeq(100)$ thin foil. The polishing of the samples for electron microscopy has been described elsewhere $/ 2 /$. 


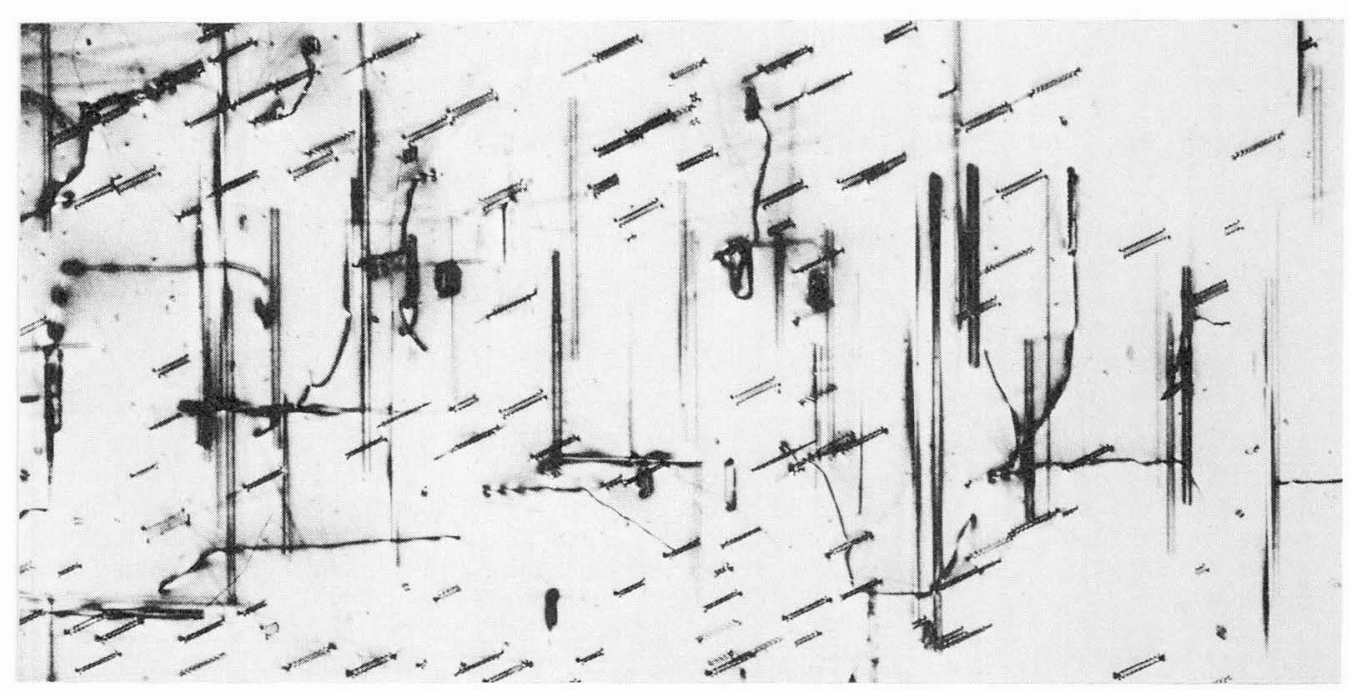

Fig. 2 - Bright field electron micrograph (1 MV) of the lattice defects found in $\mathrm{V}_{3} \mathrm{Si}$ by HVEM $/ 1 /$.

\section{II - EELS ANALYSIS OF THE PRECIPITATE BY HVEM}

This technique has been used at $1 \mathrm{MV}$. The part of the specimen which is investigated is limited by the selecting aperture to an area of about $100 \mathrm{~nm}$ in diameter. Such a probe does not allow the anaTysis of the precipitate alone ; it includes also a part of the matrix. The presence of vanadium and silicon only has been detected, so that the precipitate belongs to the binary $V-S i$ system, the phase diagram of which is shown in Fig. 3. In addition to this result, this technique has shown qualitatively that the precipitate is enriched in silicon with respect to the matrix. Taking into account both results, the precipitate is anticipated to be $\gamma-V_{5} \mathrm{Si}_{3} / 9 \%$. This result has been confirmed by EELS with the STEM and by convergent beam electron diffraction.

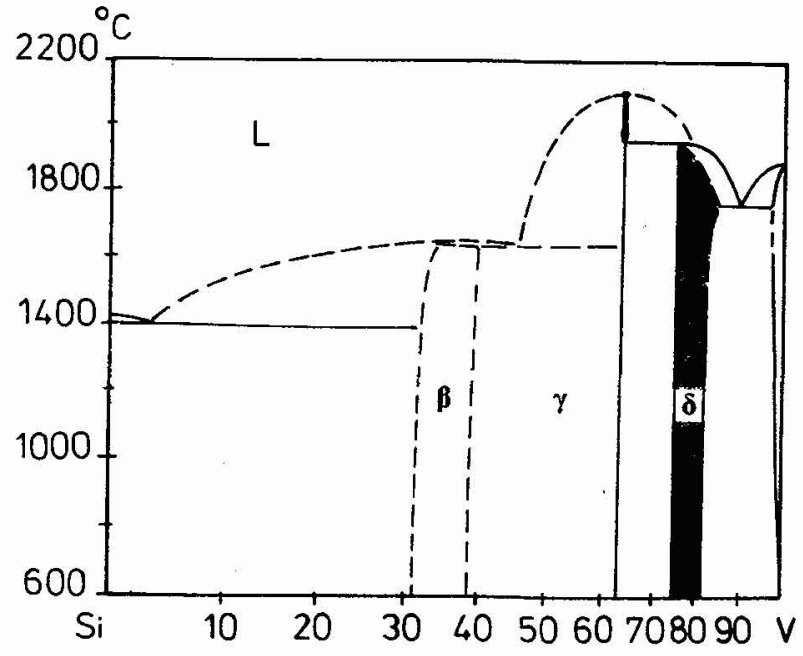

Fig. 3 - The binary V-Si system phase diagram (according to $/ 9 /$ ) showing the three compounds $\delta-V_{3} S i, \gamma-V_{5} S i_{3}$ and $B-V S i_{2}$. 


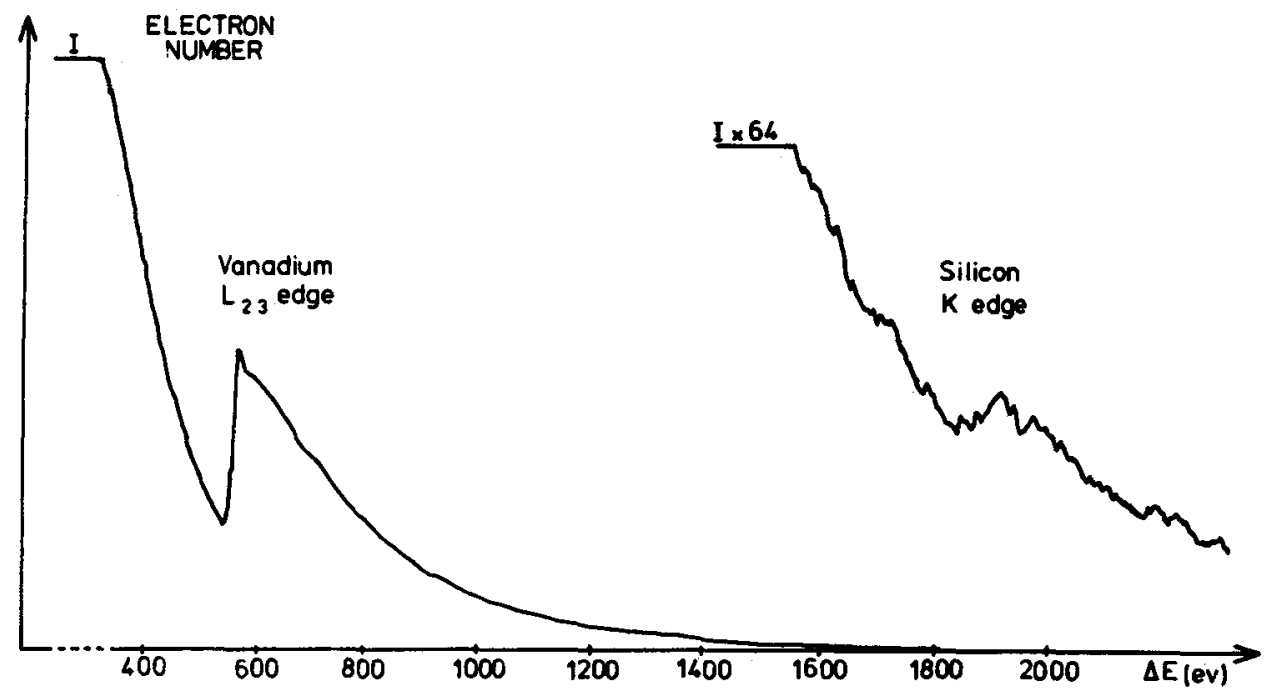

Fig. 4 - Example of a 1 MV EELS spectrum on the precipitate showing clearly the vanadium $L_{23}$ edge and the silicon $K$ edge (enlarged 64 times with respect to the vanadium $L_{23}$ edge) which have been used for the analysis.

\section{III - EELS ANALYSIS OF THE PRECIPITATE BY STEM}

In the STEM, the electron probe is held on a given specimen feature or scanned over a reduced area which can be adapted to the geometry and dimensions of the specimen to be analysed. In the present study, an area of $22 \times 15 \mathrm{~nm}$ is investigated, of the matrix, of the correctly oriented needle-shaped precipitates or of the depressions induced by polishing around them. The EELS spectra exhibit several edges for vanadium and silicon. The two low energy edges $\left(\mathrm{V}-\mathrm{M}_{23}\right.$ at $55 \mathrm{eV}$ and $\mathrm{Si}-\mathrm{L}_{23}$ at $\left.99 \mathrm{eV}\right)$ cannot be used for quantitation because they are superimposed on an intense background which cannot be adequatly represented by a power law of the form $A$. $\Delta E^{-R}$. Consequently, one has to perform the measurements from the $V-L_{23}$ edge at $507 \mathrm{eV}$ and the Si-K edge at $1855 \mathrm{eV}$, as shown in Fig. 5. The atomic ratio can be estimated as follows :

$$
\frac{N_{V}}{N_{S i}}=\frac{S_{V}}{S_{S i}} \times \frac{\sigma_{S i}}{\sigma_{V}}
$$

where $S$ denotes the signal after background stripping and $\sigma$ the calculated sigmak and sigmal cross section /10/ for the energy $(\Delta)$ and angular collection of detection used.

Two types of corrections have then to be taken into account, concerning the specimen itself and the instrument. The first allows for the influence of the strfong thickness variations, which cause multiple scattering contributions over the edges. We use the plasmon shift correction tabulated by Stephens /11/. The second is due to the chromatic error introduced by the post-specimen objective field on electrons of highly different energies ("V electrons" of $\simeq 99.5 \mathrm{keV}$ and "Si electrons" of $\simeq 98 \mathrm{keV}$ ). After calibrating this effect from the known composition of the matrix, the composition of the precipitate can be established to be $V_{x} S i$ with $1.4 \leqslant x \leqslant 1.6$, which provides a first clear identification that it is $\mathrm{V}_{5} \mathrm{Si}_{3}$. 

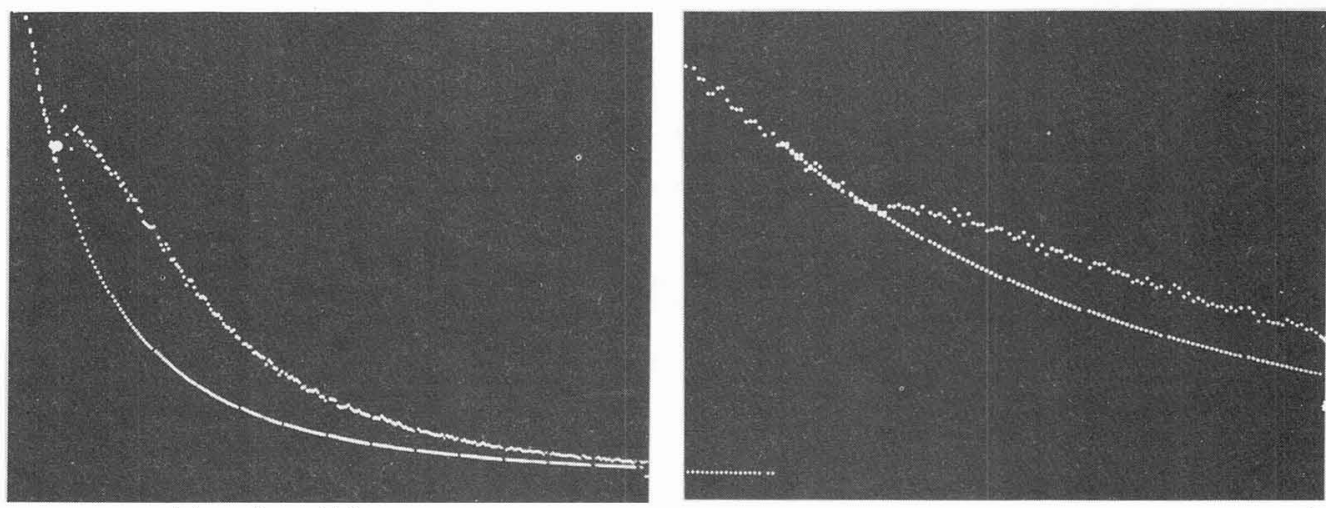

Fig. 5 - $100 \mathrm{kV}$ STEM EELS spectra on a precipitate seen edge-on in $V_{3} S i$. Enlargements of the $L_{23}$ edge of vanadium (a) and of the $K$ edge of silicon (b) are shown, together with the extrapolation of the background.

\section{IV - CONVERGENT BEAM ELECTRON DIFFRACTION}

The crystallographic nature of the precipitate has been assessed by convergent beamelectron diffraction. Fig. 6 shows a $(0 \overline{1} 2)^{2}$ diffraction pattern which confirms that the precipitate is the quadratic $\mathrm{V}_{5} \mathrm{Si}_{3}$. The crystallographic orientation relationship between the $\mathrm{V}_{5} \mathrm{Si}_{3}$ and the $\mathrm{V}_{3} \mathrm{Si}$ matrix is now under investigation using the convergent beam electron diffraction technique.

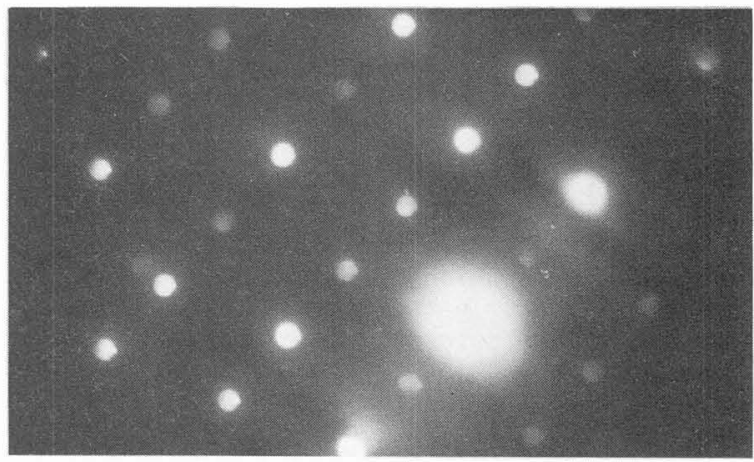

Fig. $6-(0 \overline{1} 2) *$ convergent beam diffraction pattern of the precipitate seen edge-on in the $V_{3} S i$ matrix. It corresponds to the quadratic $\mathrm{V}_{5} \mathrm{Si}_{3}$ phase.

\section{$V$ - REFERENCES}

/1/ Ben LAMine A., ReYNAud F., MAI C. et SEnATEUR J.P., Phi1. Mag. 38 (1978) 359.

/2/ BEN LAMINE A., SENATEUR J.P. et REYNAUD F., J. Microsc. Spectrosc. Electron. 5 (1980) 745.

/3/ BEN LAMINE A. and REYNAUD F., 10th Int. Congr. Electron Microsc. Hamburg (1982), vol. $2,149$.

14/ REYNAUD F. et BEN LAMINE A., Acta Met. 29 (1981) 1485.

/5/ HARRIS W.F., Phil. Mag. 22 (1970) 949.

16/ JOUFFREY B., KIHN Y., PEREZ J.Ph., SEVELY J. and ZANCHI G., 9th Int. Congr. Electr. Microsc., Toronto (1978), vol. III, 292.

17/ ZANCHI G., SEVELY J. and KIHN Y., J. Microsc. Spectrosc. Electron., 6 (1981) 599.

18/ COLLIEX C., 10th Int. Congr. Electron Microsc. Hamburg (1982), vo1. 1, 159 or COLLIEX C., TREBBIA P., U1 tramicroscopy 9, (1982) 259.

19/ Metals Handbook, vol. 8, A.S.M. (1973), $\overline{3} 34$.

/10/ EGERTON R.F., UTtramicroscopy 4 (1979), 169 or Proc. EMSA (1981), 198.

/11/ STEPHENS A.P., U1 tramicroscopy $\underline{-5}$ (1980), 343. 